\title{
Research on Cost Overrun Risk of Construction Phase of Vietnam Highway International Contracting Project
}

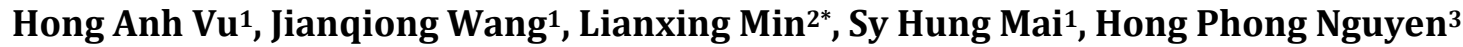 \\ ${ }^{1}$ School of Economics and Management, Southwest Jiaotong University, Chengdu, China \\ ${ }^{2}$ School of Management, Chengdu University of Traditional Chinese Medicine, Chengdu, China \\ ${ }^{3}$ School of Railway Section, University of Transport and Communications, Hanoi, Vietnam \\ Email: 584335443@qq.com, qiongsi007@126.com, "md3318@163.com, mai-hungdhxd@yahoo.com.vn, \\ nguyenphong0712@gmail.com
}

Received 19 January 2016; accepted 13 March 2016; published 16 March 2016

Copyright @ 2016 by authors and Scientific Research Publishing Inc.

This work is licensed under the Creative Commons Attribution International License (CC BY). http://creativecommons.org/licenses/by/4.0/

(c) (i) Open Access

\begin{abstract}
Recently, the highway construction projects increase rapidly in Vietnam and most of them are international contracting projects. It results serious negative influence on the local government and enterprises that the common cost overrun of projects, and the risk factors of it is different in the different countries, different stages and projects types. So in this paper, we generate an evaluation index system of highway construction projects cost overrun risk in Vietnam in the perspective of different project participants, and also evaluate the effects of these factors in method of regression analysis. The empirical results confirmed 7 main factors that have aggravated cost overrun risk in construction stages, e.g. survey and design scheme risk. In final, the corresponding suggestions are proposed to reduce the project cost overrun risk.
\end{abstract}

\section{Keywords}

Highway, Construction, Cost Overrun, Risk Management, Vietnam

\section{Introduction}

The highway is an important symbol of regional modernization and economic development, but there is no highway in Vietnam before 2002. According to the estimate of Vietnam experts in the field of transportation, it is necessary for Vietnam's industrialization and modernization to develop a modern transport system, which

${ }^{*}$ Corresponding author.

How to cite this paper: Vu, H.A., Wang, J.Q., Min, L.X., Mai, S.H. and Nguyen, H.P. (2016) Research on Cost Overrun Risk of Construction Phase of Vietnam Highway International Contracting Project. Engineering, 8, 86-98.

http://dx.doi.org/10.4236/eng.2016.83011 
contains a traffic aorta of $6000 \mathrm{~km}$ highway [1]. Although the highway construction in Vietnam has already started in the past 10 years, the highway network just accounts for a small proportion compared with the whole national transport network, and cannot satisfy the demands development. In order to build new Vietnam's national highway network, Vietnam's prime minister pointed out in a second session of the national assembly government report in 2007 with the word of "The government needs to strictly monitor and guide important investment project schedule of every country, especially in those implementation process of national key project." Planning examination and approval, releasing policy and list of social infrastructure projects, encourage domestic investors and foreign investors in appropriate form. The government guides to launch 30 strategic transport investments projects till 2020, particularly the road and highway projects. The Vietnamese government is encouraged to absorb the domestic and foreign funds by BOT, BTO, BT, PPP, etc. [2]. There are lots of projects belonging to the international cooperation projects. Although they are executed by experienced foreign enterprises, the phenomenon of cost overrun is still serious and becomes a most frequently problems in Vietnam. According to the Vietnamese economic experts, in 2011 Vietnam almost all of the highway projects costs have an unexpected increase, and the construction cost of Vietnamese highway is 1.5 to 2 times higher than other countries, such as China, Indonesia, Malaysia, Thailand, even higher than the United States, and brings more difficultly of absorbing the investors [3]. There are many reasons of cost overrun, for the large cost and complex geological conditions on site, the higher risk of highway projects than other projects [4]. The engineering project risk is numerous, which mainly includes owner, designer, supervision and contractors, subcontractors, suppliers, manufacturers, government, etc. [5]. The highway construction projects have a higher risk than other construction projects, because highway project involves wider geographic area. In general, the highway construction is a big project [6]. The large project investment, long construction period, numerous participants, complex construction technology, policy constraints and complex geological conditions make projects in construction stage and cost management more complex compared with the general construction project. Especially in Vietnam, the research and practice of project risk management began comparatively late, which lacks of management experience and related research, and qualitative analysis is more and quantitative analysis is less. Engineering costs will bring economic loss of international contracting enterprise, affect the enthusiasm of the enterprise and hurt the highway construction. Therefore, it is necessary to research the risk factors increasing the construction cost of Vietnam highway, find out the key factors influencing the stage of engineering cost, take targeted measures to improve the level of the government management and construction enterprise market competitiveness, avoid economic loss due to cost risk, and promote foreign companies more actively to involve in Vietnam highway project engineering contracting, which all have very important practical significance.

Cost overrun are defined as actual cost over budget, sometimes referred to rising costs, increased costs or budget overrun. The key to solve the problem of cost overrun is to identify the risk factors of cost overrun, which can identify factors affecting the risk of cost overrun which is a key, is also a difficulty. Understanding of risk can help the parties to reduce their negative effects on the cost overrun. Scholars respectively discussed about this from different angles. From the perspective of different stakeholders and the environment, risks are focused on in China, and the owner, survey, design and the government have to be strict management from the feasibility stage, in order to solve the potential risks that may be encountered in the construction stage; The contractor and the subcontractor must strengthen the management ability to accomplish construction stage smoothly [7]. 21 major factors causing cost overrun were identified, including changes in design, inaccurate evaluation of projects time and cost, unstable government policies, etc. which is particular in developing countries [8]. From the perspective of contractors, the factors influencing cost overrun cost overrun in construction projects in the Gaza has been researched, and 42 factors influencing cost overrun are put forward, and 8 key affecting factors, including closed boundary leading materials rise in price, schedule delay, contractor's equipment and material supply, the market price changes, the project material monopoly suppliers, unstable local currencies to the dollar exchange rate, negative impact on the economy and policy changes, the lack of subsidies and donor policy in awarding tenders to the lowest bidder [9]. Questionnaire survey was conducted by Malaysia large engineering, 35 factors influencing cost were put forward, and three main factors are concluded, which are construction material price change, difficult fiscal capacity and unreasonable distribution, and the poor ability of construction site management and supervision [10]. For influencing factors of cost overrun before the construction of highway engineering and construction phase of Sri Lanka project, and the factors are ranked according to their importance: slow payments, delay of engineering relocation, construction stage design changes, construction materials prices and land expropriation related issues, and further conclusions and Suggestions were put forward [11]. 
Through the questionnaire survey combined with expert interviews, the safety and quality, completion of previous projects, environment, management and technology, resources, organization, experience, project type and capital are the key success factors of the contractor [12]. In the United Arab Emirates (UAE) highway engineering project evaluation, 33 risk factors are pointed out that, through the relative important index (RII), key risk affecting highway are pointed out, which includes low planning efficiency, unexpected underground facilities, the design quality and integrity, slow approval and land acquisition delay [6].

In Vietnam, the research of project risk management began comparatively late, the current study focused on learning and digestion of western related theory, which are mainly qualitative analysis and lack of quantitative analysis, and the consciousness of cost risk was thin, which lack of system discussion of related factors. Through questionnaire survey, cost overrun risk of Vietnam construction project are pointed, the results show that there are seven main factors that affect the construction progress and cost of construction project, including slow payments, absence of restrictions, management ability, design, financial and budget risk, financial ability, government and technology labor [13]. Cost overrun risk mainly comes from construction stage, and Vietnam construction project risk mainly exist in owner management, staff ability and external environment according to questionnaire survey [14]. The risk factors and their impacts, such as the owner, contractor, supervision unit, survey and design unit, environment changes and policy changes, are recognized and confirmed in the literature, but there are few researches discuss them in together, and these studies neglected the influence of the characteristics of different types of infrastructure projects. And because of many characteristics of highway construction, such as the large investment, long construction period, complex construction technology, many participant units, complex topography and geological conditions and construction policy constraints, project schedule management is more complex than other project. And in different countries and regions, different project areas and different stages, the risk factors influencing the construction progress is different.

To sum up, in developing countries like Vietnam, the phenomenon of cost overrun of projects is a very common and leads to bad results, that's why we should to make a reasonable evaluation of cost overrun and take measures to cope with it. In this paper, based on the literature review at home and abroad and the perspective of different project participants, we generate an evaluation index system of highway construction projects cost overrun risk in Vietnam, and also design and implement the questionnaire to collect the data of 54 indexes. Then, we use the method of factor analysis and extract 7 factors from the 54 indexes. Using the regression analysis method, we examine and confirm the relationship between these 7 factors and cost overrun. In final, we analyze the features of 7 factors in real construction practice and give the advices to promote the development of Vietnamese highway and provide important practical significance of risk management of the investment enterprises who want to participate in the Vietnamese highway projects.

\section{Questionnaire Design}

In this paper we determine the factors affecting cost overrun of highway projects in Vietnam by interviewing the 6 Vietnamese experts have experience more than 20 years in the field of engineering construction. They are from 1 owner unit, 1 contractor unit, 2 design units and 2 universities. The indexes system contains 54 indexes in Table 1. Meanwhile Likert5 scale is adopted in the questionnaire. 1 is smallest, 5 is biggest. The higher the score, the greater the impact.

\section{Characteristics of Respondents}

Respondents in this paper cover the multiple Vietnamese highway construction projects, and effectively reduce the potential errors of non-random sample. Respondents mainly comes from the Vietnam personnel related working on the highway construction projects, such as Vietnam ministry of communications, project management unit, supervision unit, the staff of contractor and the owner. And they all have certain experience in engineering projects and could ensure the validity and accuracy of the survey.

The questionnaire is distributed by e-mail, post-mail and field investigation. Field investigation can improve the respondents' participation of filling in the questionnaire, but the scope is small. Therefore, the e-mails and letters are also adopted to distributed questionnaire.

In process of the survey, we send altogether 300 questionnaires and recover 229 copies, and the questionnaire returns-ratio is $76.3 \%$. Actually, there are 197 valid questionnaire responses after eliminating the questionnaire with data missing. As is shown in Table 2, the response rate from owners, contractors, subcontractor, survey 
Table 1. Latent variables and measurement indicators.

\begin{tabular}{|c|c|}
\hline Latent variable & Index \\
\hline \multirow{3}{*}{$\begin{array}{c}\text { Owner fiscal ability } \\
\text { risk }\end{array}$} & Owners’ financial difficulties. \\
\hline & Unreasonable use and allocation of funds. \\
\hline & Slow payment settlement of completed work. \\
\hline \multirow{7}{*}{$\begin{array}{c}\text { Management ability } \\
\text { risk of project } \\
\text { management }\end{array}$} & Failure of land expropriation. \\
\hline & Poor management and control ability of project management team. \\
\hline & Projects design changes. \\
\hline & accidents in construction stage is not handled in time. \\
\hline & The conflict between owners, contractors, supervisors, and local government organization. \\
\hline & Improper bidding method and evaluation index. \\
\hline & Improper management contracts, which are easy to cause the contract dispute. \\
\hline \multirow{3}{*}{$\begin{array}{c}\text { Contractor fiscal } \\
\text { capacity and fiscal } \\
\text { management risk }\end{array}$} & Contractors’ financial difficulties. \\
\hline & Unreasonable use and allocation of funds. \\
\hline & Inaccurate tender offer. \\
\hline \multirow{3}{*}{$\begin{array}{l}\text { Management risk of } \\
\text { machinery and } \\
\text { materials of contractor }\end{array}$} & The lack of manpower and poor construction ability. \\
\hline & Improper work plan of preparation machinery. \\
\hline & Supply work of prepare material is not up to par. \\
\hline
\end{tabular}

Poor ability of construction and management of contractor.

Technology difficulties of construction technology and application of new construction.

Construction schedule of design project is not reasonable.

Contractor's organization management and technical ability risk
Construction need rework when its quality does not meet requirements need.

Work amount of construction increase.

Unreasonable construction layout.

Traffic system of construction site is not smooth.

Management and subcontractor contract is not reasonable, which is easy to cause the contract dispute.

The poor of monitoring subcontractor in construction process.

Industrial accidents.

\begin{tabular}{|c|c|}
\hline $\begin{array}{c}\text { Selection and } \\
\text { management of } \\
\text { subcontractor risk }\end{array}$ & $\begin{array}{l}\text { Selection of subcontractor is not reasonable. } \\
\text { The subcontractor payment settlement is slow. } \\
\text { Poor construction ability of sub-contractor. }\end{array}$ \\
\hline $\begin{array}{l}\text { Supervision unit } \\
\text { ability risk }\end{array}$ & $\begin{array}{l}\text { Monitoring work ability of supervision unit is poor. } \\
\text { The ability of guide contractor to deal with sudden accidents is poor. } \\
\text { The ability of guide contractor to deal with sudden accidents is poor. } \\
\text { Acceptance of work completed is slow. } \\
\text { Supervising personnel lack sense of responsibility. }\end{array}$ \\
\hline $\begin{array}{l}\text { Survey and design } \\
\text { unit ability risk }\end{array}$ & $\begin{array}{l}\text { Survey and design work ability of survey and design units is poor. } \\
\text { Geological conditions of actual construction is inconsistent with geological conditions of survey and design. } \\
\text { Overall plan of design construction is unreasonable which leads crashing. } \\
\text { Difficulties and feasibility that design does not consider construction. } \\
\text { Discrepancies between design and technical standards. } \\
\text { Drawing fails to deliver on time. }\end{array}$ \\
\hline Policy risk & $\begin{array}{l}\text { Policy changes of infrastructure construction investment. } \\
\text { Policy changes of land requisition compensation. } \\
\text { Complex investment process and administrative procedures. } \\
\text { Bidding management policy is not perfect. } \\
\text { Tax policy is not stable. } \\
\text { Wage policy changes. }\end{array}$ \\
\hline $\begin{array}{l}\text { Social environment } \\
\text { change risk }\end{array}$ & $\begin{array}{l}\text { Price fluctuation of construction material. } \\
\text { Appreciation of exchange rate. } \\
\text { Increasing of loan interest rate. } \\
\text { Changes of imported special machinery, equipment and materials. } \\
\text { Local social customs and habits. } \\
\text { Difficult relationship with local government. }\end{array}$ \\
\hline $\begin{array}{l}\text { Natural environment } \\
\text { change risk }\end{array}$ & $\begin{array}{l}\text { Complex local geological conditions. } \\
\text { Unfavorable climatic conditions. }\end{array}$ \\
\hline
\end{tabular}


Table 2. Respondents constitute.

\begin{tabular}{cccc}
\hline & Sample distribution & Sample size & Percentage (\%) \\
\hline \multirow{3}{*}{ Work experience } & 1 - 3 years & 55 & 28.1 \\
& 4 - 6 years & 70 & 35.4 \\
& $7-10$ years & 45 & 23 \\
& Above 10 years & 27 & 13.5 \\
\hline \multirow{3}{*}{ Project participants } & Owner & 31 & 15.7 \\
& Contractor & 50 & 25.3 \\
& Subcontractor & 34 & 17.4 \\
& Supervision unit & 29 & 14.6 \\
& Survey and design unit & 53 & 27
\end{tabular}

and design and consultants is $15.7 \%, 25.3 \%, 17.4 \%, 14.6 \%, 27 \%$ respectively. Regarding the respondents' experience in engineering construction, there are $28.1 \%$ of respondents have less than or equal to 3 years, $35.4 \%$ of them have between 4 and 6 years, 23\% of them have between 7 and 10 years and $13.5 \%$ of them have 10 years or more. It would be better if the percentage of respondents whose experiences are 10 years or more can be increased. From the perspective of the respondent structure, most of them have more than 3 years working experience, have a certain understanding and are able to provide survey information. The respondent distribution of different interest subjects, such as owners, contractors, subcontractors, supervision unit, is relatively balanced, which fully reflects the opinions of different stakeholders. Meanwhile, respondent are mainly middle managers, both including low-level managers and senior managers, so that the investigation fully and accurately reflects all kinds of information in the project.

\section{Empirical Analysis}

In this study, we make exploratory factor analysis on data by SPSS20 statistical software, and the factor analysis was conducted by principal component analysis and maximum variance method.

\subsection{The Results of Factor Analysis}

The first step is model checking. Table 3 shows the corresponding test results, in which the KMO value is 0.815 (>0.5), Bartlett Sphericity Approximate Chi-Square test value is 2541.520, and the significant $\mathrm{p}=0.000$ (sig < 0.05). All results are indicating that the variables are suitable for factor analysis.

The second step is to calculate the eigenvalue and variance explained. From Table 4, We can select 7 factors according to the principle of the eigenvalue $\lambda_{i}>1$ and the cumulative variance explained of the selected 7 factors reached 74.756 ( $>50 \%)$. It shows that the selected 7 factors basically reflect the most information of construction delay.

The third step is to build the factor load matrix. According to the results of matrix exploratory factor analysis in Table 4, the factor index load can be divided into 7 categories. Project design changes, difficulties in construction and feasibility, complex topography and geological changes, unmatched design technical standard, inconformity between actual construction geological conditions and survey geological conditions are more associated with the first factor named survey and design scheme factor (Factor 1). Complex recruit investment process, improper way of bidding and evaluation indicators, low tender offer, inappropriate selected subcontract are more associated with the second factor named infrastructure construction investment management system factor (Factor 2). The insufficient owner fiscal capacity, slow payment of completed work, unreasonable funds allocation and improper management construction contract are more related to the third factor named capital and contract constraint factor (Factor 3). Poor ability of contractor financial, poor ability of contractor construction management and poor ability of subcontractor construction are more relevant with the fourth factor named construction unit fiscal and management ability factor (Factor 4). Failure to finish the land expropriation, land requisition compensation policy changes and difficult relationship with local government are more relevant with 
Table 3. KMO test and Bartlett sphericity test.

\begin{tabular}{lcc}
\hline \multicolumn{2}{c}{ Kaiser-Meyer-Olkin measure of sampling adequacy. } & 0.815 \\
\hline & Approx. chi-square & 2541.520 \\
Bartlett's test of sphericity & df & 276 \\
& Sig. & 0.000 \\
\hline
\end{tabular}

Table 4. Component matrix after rotating.

\begin{tabular}{|c|c|c|c|c|c|c|c|}
\hline Causes of cost overrun & Factor 1 & Factor 2 & Factor 3 & Factor 4 & Factor 5 & Factor 6 & Factor 7 \\
\hline Projects design changes & 0.898 & & & & & & \\
\hline $\begin{array}{l}\text { Difficulties and feasibility that design does not consider } \\
\text { construction }\end{array}$ & 0.885 & & 0.121 & & & & \\
\hline Complex local geological conditions & 0.785 & -0.173 & & 0.141 & & & 0.198 \\
\hline Discrepancies between design and technical standards & 0.778 & -0.128 & 0.215 & 0.153 & & & 0.132 \\
\hline $\begin{array}{l}\text { Geological conditions of actual construction is inconsistent } \\
\text { with geological conditions of survey and design }\end{array}$ & 0.778 & 0.333 & 0.116 & & & & 0.131 \\
\hline Complex investment process and administrative procedures & & 0.857 & 0.166 & 0.175 & & & \\
\hline Improper bidding method and evaluation index & & 0.844 & 0.165 & 0.191 & 0.142 & & \\
\hline Inaccurate tender offer & & 0.840 & 0.139 & 0.120 & 0.145 & & \\
\hline Selection of subcontractor is not reasonable & & 0.732 & 0.142 & & 0.204 & & \\
\hline Owners' financial difficulties & 0.119 & 0.112 & 0.825 & 0.141 & & & 0.118 \\
\hline Slow payment settlement of completed work & 0.117 & 0.152 & 0.817 & & & & \\
\hline Unreasonable use and allocation of funds & & 0.118 & 0.804 & 0.247 & & 0.127 & \\
\hline $\begin{array}{l}\text { Improper management contracts, which are easy to cause } \\
\text { the contract dispute }\end{array}$ & 0.218 & 0.271 & 0.657 & & & & 0.155 \\
\hline Contractors' financial difficulties & 0.147 & 0.185 & 0.113 & 0.845 & & & \\
\hline Poor ability of construction and management of contractor & 0.149 & 0.246 & 0.135 & 0.815 & & & \\
\hline Poor construction ability of sub-contractor & 0.118 & & 0.140 & 0.811 & & & 0.165 \\
\hline Failure of land expropriation & & 0.243 & & 0.110 & 0.836 & & \\
\hline Policy changes of land requisition compensation & 0.119 & & & & 0.830 & 0.179 & \\
\hline Difficult relationship with local government & 0.181 & 0.132 & & & 0.798 & & 0.119 \\
\hline Price fluctuation of construction material & & & & 0.106 & & 0.857 & \\
\hline Increasing of loan interest rate & -0.115 & 0.148 & & & & 0.836 & \\
\hline Appreciation of exchange rate & & & & & 0.219 & 0.753 & -0.222 \\
\hline Acceptance of work completed is slow & 0.189 & & & & & & 0.858 \\
\hline Supervising personnel lack sense of responsibility & 0.253 & & 0.142 & 0.126 & & & 0.836 \\
\hline Eigenvalues & 6.029 & 3.695 & 2.167 & 1.837 & 1.657 & 1.392 & 1.165 \\
\hline Variance explained \% & 25.120 & 15.396 & 9.028 & 7.654 & 6.905 & 5.800 & 4.852 \\
\hline Cumulative Variance explained \% & 25.120 & 40.616 & 49.544 & 57.198 & 64.104 & 69.904 & 74.756 \\
\hline Cronbach's Alpha & 0.905 & 0.879 & 0.828 & 0.841 & 0.810 & 0.762 & 0.768 \\
\hline
\end{tabular}

the fifth factor named land acquisition factor (Factor 5). Prices of construction materials, appreciation of exchange rate, loan interest rate increase are more relevant with the sixth factor named macro-economic environment changes factor (Factor 6). Slow acceptance work of supervisor, supervisor lack the sense of responsibility are more relevant with the seventh factor named the supervising moral risk factor (Factor 7). While the correla- 
tion between the rest of the variables and factors does not conform to the research setting, therefore, we delete them in the further data analysis. Cronbach's Alpha of every factor is larger than 0.7 , which means that the extracted factors have high reliability.

The fourth step is to obtain the factor score. The factor model can make the variables expressed as a linear combination of a common factor, meanwhile it can make the common factors expressed as a linear combination of the original variables, and the factor score coefficient is obtained by the following formula (1).

$$
F_{i}=\sum_{j=1}^{19} K_{i j} X_{j}
$$

Among them, $F_{i}$ represents the factor scores, $i \leq 5 ; K_{i j}$ represents the weight coefficient for the $j$-th index in the $i$-th factor; $K_{j}$ represents the $j$-th indicator's observation values.

\subsection{Regression Results}

Results of regression analysis are shown in Table 5 . The adjusted R-squared value is 0.636 , which shows that the influence factors are more comprehensively taking into account. The value of $\mathrm{F}$ is 49.826 and significant on the level of $1 \%$, indicating that the model settings are reasonable.

The standardized coefficient of each factor is positive and significant (Table 5), so we can conclude that any factor has a positive impact on the delay of construction schedule, and the test results of 7 factors are all significant in the level of $10 \%$. Based on the standard coefficients, we can also find that the impact of all kinds of factors on the construction schedule delay are different, and the estimated value varies from 0.125 to 0.397 . The largest impact on the construction schedule delay is infrastructure construction investment management system factor (0.397), followed by survey and design scheme factor (0.395), land requisition factor (0.342), construction unit fiscal and management ability factor (0.319), capital and contract constraint factor (0.276), macroeconomic environment changes factor (0.153), supervising moral risk factor (0.125).

Table 5. Regression analysis results.

\begin{tabular}{ccc}
\hline Factor & Standardized coefficients & Value of $\mathrm{t}$ \\
\hline Survey and design scheme factor & 0.395 & $9.166^{* * *}$ \\
Infrastructure construction investment management system factor & 0.397 & $9.216^{* * *}$ \\
Capital and contract constraint factor & 0.276 & $6.399^{* * *}$ \\
Construction unit fiscal and management ability factor & 0.319 & $7.406^{* * *}$ \\
land requisition factor & 0.342 & $7.941^{* * *}$ \\
macro-economic environment changes factor & 0.153 & $3.548^{* * *}$ \\
Supervising moral risk factor & 0.125 & $2.894^{* *}$ \\
Value of $\mathrm{F}$ & & $49.826^{* * *}$ \\
Value of $\mathrm{R}^{2}$ & & 0.649 \\
Adjusted $\mathrm{R}^{2}$ & & 0.636 \\
\hline
\end{tabular}

Note: ${ }^{* * *}$ Stands for level $1 \%$ significantly, ${ }^{* *}$ Stands for level $5 \%$ significantly, ${ }^{*}$ Stands for level $10 \%$ significantly.

\section{Realistic Analysis and Corresponding Suggestion of the Risk Factors}

\subsection{The Risk of Investment Management System in Infrastructure Construction}

The factors include that, the investment of construction stage and complex administration approval process; the improper bidding mode (such as contract mode and evaluation index); the low tender price; the improper choices of subcontracting and sub-contractors. The director of Hanoi economic development institute, Dr. Nguyen, thinks that in Vietnam the investment of infrastructure construction is so complex, there are corruption risks in every stage, therefore the cost of engineering increase [3]. And since the indeterminate bid evaluation and decision method, in addition, the tendering and bidding is not so irregular, as a result, the phenomena that contractors and employers collude is common. The tenderee and competent department just make a form, actually the 
company which wins the bidding is already decided. In order to win the bidding, some contractors even ignore the costs and profits, they offer a well below reasonable price on purpose, and then claiming in various ways during the construction stage. In Vietnam, because there are no distinct responsibilities and authorities between contractors and sub-contractors, the contractors win the bidding in a low price deliberately, if the construction went on, they may lose money or cheat in work and cut down on materials, therefore it will have an effect on the engineering quality. In that case, the engineering assignment to sub-contractors will be the best choice. In this way, they will get the subcontract interest without construction. So the phenomena that contractors transfer one part of the project or even the main part to sub-contractors randomly is common. As a result, there are so many participants in one project, the construction is more complex and the costs increased.

The government of Vietnam need perfect investment management system of infrastructure construction, simplified administrative examination and approval procedures, especially the related tendering and bidding process and relevant laws and regulations during construction stage. The government is expected to form independent tendering and bidding supervision and administration department, therefore they can strengthen the effective supervision of the tendering and bidding process, and make strict tendering and bidding agency qualification management. In this way, the tendering and bidding process is more open and the corruption behavior can be prevented. At the same time, they should check the pre-qualification of the contractors strictly and review and verify the tender documents of the contractors. In addition, they are expected to impose the relevant legal provisions and make the tendering and bidding process more professional. During the process of tendering and bidding, they should set the bottom price under the premise of ensuring the project duration and quality, dismiss the bids which are at a very low price, and adjust the uniform definition of contractors and subcontractors in written form. At last, they should make the responsibility and authority of each member of the consortium clearly in law, the contractors should be designated not to transfer the main project, and complete the tender documents and quality management mechanism and model contract of sub-contractors and so on. When the contractors and sub-contractors sign contracts, they should get the consent and recognition of the employers. If finding that the sub-contractors' ability couldn’t achieve the requirements, they should be replaced immediately.

\subsection{The Risk of Survey and Design Scheme}

The factors include that, change of project design, designing without considering the difficulty and feasibility of the construction, complex topographic and geological change, inconformity of technical design standard, inconformity between actual geological construction conditions and geological conditions of survey and design and so on. The design of Vietnam engineering project is always changing [13] [15]. There are mainly objective reasons and subjective reasons, especially the objective reasons. When considering the subjective reasons, Vietnam belongs to coastal area, which has long and narrow terrain and transitional characteristics. So the geographical conditions are very complex, and it is easy to lead to inaccurate or missing survey data, or there is no expected risk in the construction of underground works like unknown underground pipeline that results in the change of design project. While considering the objective reasons, because the employers lack professional knowledge and have weak risk management consciousness, they attach less importance to the design of engineering project and just want to make design quickly during engineering design stage, in addition, the men who are responsible for planning just push the designers to give their drawings. Therefore, they ignore the economical rationality of the design scheme, the cost of design scheme and whether it is reasonable. And the designers just give drawings without considering whether they are reasonable in economics. So the design is often too conservative. At the same time, in order to meet the design progress of the employers, the survey and design company often make unmatched professional design and technical standards. As a result, the quality of the project design is not so well. These factors lead to the design often unqualified and bring the difficulty to construction. Therefore, the construction isn't go on well and they have to change the project design and construction methods, sometimes they even do poorly done work over again. As a consequence, they have to do more work and the cost of the project is also seriously affected by them.

Although the design expenses account for little proportion in the total cost of construction projects, only about $2 \%$ of the construction and installation cost in general, but they have a large effect on the project cost, sometimes even reach to $75 \%$ [16]. So the employers and relevant administration should strengthen the risk management of cost, and try to choose excellent design companies while bidding. At the same time, the ISO standards can be applied to the project design in order to improve maneuverability of the design. A good design not only requires better economic and social benefits, but also has economic rationality. While designing, they are ex- 
pected to consider the possibility and economic of construction fully, and they should try to meet the requirement of standards and control the change of design strictly to ensure the investment not to exceed the limit easily. In order to implement quota design and establish reward and punishment system, they take vertical and horizontal control in the project cost. Not only control the whole budget of the construction drawings within the preliminary approved design estimate, but they should divide the whole project into several projects. And for the distribution of quota design index, they can also establish reward and punishment system to make sure the quality of index distribution. In addition, because the designers lack the concept of economics, when signing contracts, they should take some restraint measures like increasing restrictive clauses which is about design change and the modification of expense limit, if the design change is beyond a certain proportion of the construction contract price, the designers should be deducted a certain proportion of design fees. At the same time, they should strengthen the examination before the design drawings are out and overcome the shortcomings or deficiencies of the design. Only in this way, they can improve the design quality and avoid increasing engineering cost due to design during construction stage. In addition, the contractors should not use survey data of engineering geology and hydrology too much. They are expected to strengthen the outdoor survey to ensure the basic data is reliable and comprehensive. During construction stage, they should organize the relevant departments like design engineers, survey engineers and experts to comply with each other strictly. And they should take targeted measures to deal with soft foundation design and construction control.

\subsection{The Land Requisition Risk of Project Site}

The factors include that, the failure to complete the land requisition on time; the changes of land acquisition compensation policy; the bad relationship with local government. In Vietnam, land requisition is a very difficult problem [3]. Although many projects have reached the construction phase, the owners still handed over only part of the land to the contractor. The owners still cannot be promptly handed over another part of land to contractor when the contractor has completed the construction of part of the land yet, resulting in construction affected. A major reason is that people are generally accustomed to living beside the road in Vietnam, resulting in a large cost of acquisition compensation. Besides, the frequently change of land acquisition policies, the poor management, the lack of uniform standards in compensation and resettlement price regulations, the improperly cadre management of land acquisition, the lack of cooperation with the local government, the illegal acts such as bureaucracy, corruption in local government, the disposal not strictly in accordance with compensation and resettlement regulations, the phenomenon of opposition to land resettlement and compensation lawsuit caused by the irrational compensation, lead to the difficulties in land acquisition. Due to the slow land acquisition, some items were paralyzed delayed for about two to three years, even been extended to five years so that a continuous rise in the cost of land acquisition then cost ratio increased to twice the original investment. The costs of land acquisition average accounted for $8 \%$ - $10 \%$ of the total investment from the statistics of Vietnam highway Ministry of Transport [15]. And it can be a reason that contractors claim higher pay when the slowly transfer of land result in delays in the construction schedule, therefore the total investment is higher than original and project financing mainly from loans such as the ADF concessional loans, OCR ordinary loans and national debt securities. The extension of time will increase the interest rate.

The government should do land work well to safeguard the smooth commencement of construction. Firstly, government departments need to further improve the standard of land acquisition procedures, strengthen land management, and earnestly safeguard the legitimate rights and interests of landless peasants. Secondly, government should resettle them before the demolition, to ensure that long-term living level of landless farmers is not lower than the original. Thirdly, supervision of land acquisition costs should be strengthened, and the implement of land acquisition and management of cadres to should be open, strictly in accordance with the compensation standards and resettlement regulations. Furthermore, the publicity work before the approval of land acquisition should be done first. The project management office should take the initiative to cooperate with the local government and various groups to disseminate in the name of country that the economic and social benefits we get from the project. In addition, land acquisition costs should have a specific dedicated funding program before the investment. The charges of last year can be used to supplement this year's spending rules to ensure the cost of the initiative.

\subsection{The Risk of Construction Unit's Financial and Management Capacity}

The factors include that, financial capacity difficulties of contractors; poor construction management of con- 
tractors; poor construction ability of subcontractors. In Vietnam, the phenomenon of an increasing cost due to the poor financial capacity of the contractor's is very much [13]. The main reason is that owners simply pursuit the low-cost and don't have scrutiny on contractor qualification in the bidding process. Especially the "anchored behavior" of some irregularities enterprise, namely that unqualified contractors borrow qualified contractors' qualification to bid, and then unqualified contractor responsible for the construction if they win the bidding. This behavior leads to that poor ability contractors get the projects, and the contract also lack the financial capacity constraints to the contractor, resulting in that the contractor does not have enough funds for the procurement of raw materials, labor, equipment, etc. or timely pay to the subcontractor directly affects the efficiency and increases the cost of the project in project construction process. Meanwhile, the contractor's management ability is poor, so the monitoring and coordination of subcontractors during construction is insufficient. Subcontractors are mainly small businesses that have poor construction technology, lack of equipment, and no experience of large-scale projects, resulting in a waste of construction materials in the construction and construction quality cannot up to standard, then the work should be reworked. It will lead to increased construction costs.

Before bidding contractors' qualification should be strictly examined. Through the projects that contractor has completed, we can investigate the experience and ability of the bidders. Owners should pay more attention to its past experience of successful projects, rather than the pursuit of low prices. To inspect when necessary, avoid "affiliated" and other irregularities. When the owner and the contractor signed a contract, owners should require the contractor to provide its financial plan and review its project execution capabilities, in order to avoid the risk of using its own funds in the course of the project execution. Contractors should have a clear evaluation system in the selection of subcontractors, strengthen coordination between departments and the management of the subcontractors in the construction process, enhance communication and understanding and reduce differences. In accordance with the combination principle of "responsibility, rights and interests," each unit should define their respective responsibilities and mandates, implement appropriate incentive measures, increase the enthusiasm and creativity of work, to achieve productivity gains and cost improvement.

\subsection{The Risk of Capital and Contractual Constraints}

The factors include that, the insufficient financial capacity of owners; the slow payment and settlement of the completed work; the unreasonable allocation of funds; the contract disputes that construction contract mismanagement prone to. According to the relevant documents, the highway project's capital should be not less than $30 \%$ of the total investment, but in fact very few can really achieve this requirement. The majority of sources of funds is complex, including the National Bonds, the government attract investment, domestic loans and so on, and in Vietnam there is a common phenomenon in the construction process that the large number of projectspecific funds were misappropriated, diverted, and offset lead to unreasonable funding arrangements, then cannot be paid under the contract for the construction unit during construction progress billings. Or owners are not precise enough when design a construction contract, there is always a deviation of the risk of distribution in the contract between the owner and contractor awareness, and the various uncertain events encountered in the process leading to the conflicts between construction owners and contractors when settle the quantities and leading to project price dispute, causing chaos in construction program. The capital chain rupture caused by that contractor has not received workload payment from the owners, will inevitably affect the progress of the project, reducing the efficiency of investment and increasing costs.

The government should strengthen law enforcement supervision, standardize the behavior of the owners, and lead the business management really into the legal system. When Client Payment Guarantee System promoted, owners should have clear and fixed dedicated funding projects and establish a reasonable financial plan, perform construction cost to the contractor according to the contract. In addition, the contractor should distribute reasonably and arrange a construction schedule, indicate the relationship between workload and implement workload time according to the owner's funding ability. Then the constructor submits the plan to the owners to review, and they implement peer guarantees and share the risks. In the acceptance stage, contractor should be ready for the preparation of settlement, and recover of the owners in time which have not settled for projects, to ensure the timeliness of funds throughout the construction process. At the time of conclusion of the contract, be sure to consult an experienced engineering consultants and legal experts, the foreseeable factors should be clarified and appointed in the contract, to avoid disputes and the bid cost as much as possible close after the completion of the actual project cost settlement. To strengthen risk management contracts in the performance of the contract process, management personnel should be very familiar with engineering technology and related laws and regu- 
lations. Or the FIDIC contract model can be used, this model has a standard contract conditions, can reasonably and fairly distribute risks and responsibilities between the contracting parties, clearly stipulates the rights and obligations of both parties, largely avoid additional expenses and related disputes due to the performance on contract unconscientiously.

\subsection{The Risk of Macroeconomic Environment Changes}

The factors include that, the rise of construction materials price; exchange rate appreciation; loan interest rate increase. In developing countries, macroeconomic environment changes often appear, directly affecting the engineering cost [13] [14]. Because the period of highway project construction cycle is long, procurement for the project is the main component in the construction process, and the supply and allocation of the project resources mainly rely on the market force. It often occurs in the process of large-scale engineering construction that the engineering changes cause the change of the material requirements and inflation. If procurement activities were done at this time, the price change of raw material, manpower and equipment would lead to the impact on the project cost. On the economic front, for foreign currency is used in the settlement of international procurement, the rise of exchange rate will make local currency to pay more, thus increase the purchase cost. At the same time, loans are the generally highway financing sources, so the dependence to the change of interest rate and loan time limit is very big, which makes it prone to financing risk.

Before the contractor contracts the project in Vietnam, it is necessary to reasonably analyze price risk in the process of purchasing, strengthen the known of the material markets in Vietnam, sign long-term contracts with qualified manufacturers, classify the high cost, reduce as far as possible by calculation, and formulate a scientific procurement process. When signing the contract with the owner, some related cost should be adjusted according to the Vietnamese market changes in a legal way, in order to avoid the construction material price change and the financial risks brought by it. When bidding for a project, the contractor should think carefully about their own capital, loans and project operation risk to formulate the reasonable bid amount. The contractor can work together with the bank, by using the bank's own capital and credit to provide credit guarantee for the contractor to provide investment risk management. By strengthening the cooperation between enterprises, integrating resources and using the form of joint bidding, vicious price competition can be avoided and a win-win situation can be achieved.

\subsection{The Risk of Supervision Moral}

The factors include that, slow acceptance of completed work by supervision personnel, insufficient sense of responsibility of supervision personnel. For supervision units supervise on construction on behalf of the owner and be responsible for the construction quality, good professional ethics is the basic condition of supervision engineer. In Vietnam, due to the lack of the sense of responsibility of the supervision personnel, there are often two cases: intentionally baffling contractors to seek private interests by acceptance of the completed work slowly or colluding with the contractor to cut corners, fraud, be signing qualified for eligible construction project, thus reducing the project quality. Although there are many projects that haven't been completed in Vietnam, some completed work has already appeared the phenomenon of damage [3], for which causes rework and increasing costs.

It's needed to improve the quality of supervision personnel by strengthening training, propaganda and learning. Establish and improve the personnel appraisal system and give a fair remuneration. Increase the sense of responsibility of supervision personnel through system and economic means. Supervisors must have a high sense of responsibility to guarantee the normal operation of work. However, specific binding legal liability is limited, so the limitation of supervision engineer's responsibility should be increased on the basis of the related laws and regulations and the agency appointment contract. When there is a personal negligence of supervision engineer work, breaching the contract, the supervision enterprise should bear the corresponding liability for the breach of contract, and the supervision engineer should undertake the joint liability. After the supervision enterprise takes its responsibility, according to the employment agreement or liability insurance, it shall have the right to the appropriate partial loss recovery from fault liability of supervision engineer.

\section{Conclusions}

The highway construction and project management in Vietnam are just springing up in recent years, so the level 
of project construction management is low, and it is lack of professionalism and enough attention, causing serious increase of project cost and seriously affecting the construction enterprise's investment enthusiasm at home and abroad. Therefore, on the basis of predecessors' research, in combination with the practical situation of Vietnam project construction, this paper puts forward a Vietnam highway construction phase cost overrun evaluation model including 54 risk factors. Based on the questionnaire survey data, through factor analysis and regression analysis, it summarizes seven factors influencing over cost of Vietnam highway on construction stage. According to the effects, the risk factors are sorted as the following: infrastructure construction investment management system risk, survey and design scheme risk, land acquisition risk, construction unit fiscal and management ability risk, capital and contract constraint risk, macro-economic environment changes risk and supervising moral risk.

The results show that the main reason of cost rising of the Vietnamese highway construction projects is the human factors at the early stage of the project construction phase or the incomplete management. Vietnam government departments need to improve infrastructure construction, investment process, administrative procedures and the relevant laws and regulations of construction phase, and make it conform to the actual situation. It should strengthen the management of supervise the bidding, strengthen law enforcement supervision and regulate the behavior of the owner's, and regulate the responsibility as well as corresponding rewards and punishment clearly. It should have a fair supervision mechanism to improve the owners, especially the national investment project risk management consciousness.

\section{Acknowledgements}

This work was financially supported by National Natural Science Foundation of China (71271175), Youth Foundation Project of the Ministry of Education Research of Social Sciences (12YJC630096) and Soft Science Project of the Science and Technology Department of Sichuan (2014ZR0028).

\section{References}

[1] http://118.70.241.18/english3/news/?21650/dinh-huong-phat-trien-duong-o-to-cao-toc-va-huong-thu-hut-cac-nguon-vo n-dau-tu-xay-dung-duong-cao-toc.htm

[2] http://thutuong.chinhphu.vn/Home/Bao-cao-cua-Chinh-phu-do-Thu-tuong-Nguyen-Tan-Dung-trinh-bay-tai-ky-hop-thu -2-Quoc-hoi-Khoa-XII/200710/10828.vgp

[3] http://www.cengroup.vn/78/tin-tuc-du-an/duong-cao-toc-nao-cua-viet-nam-ngon-phi-khung-nhat-n1830.html

[4] Zayed, T., Amer, M. and Pan, J. (2008) Assessing Risk and Uncertainty Inherent in Chinese Highway Projects Using AHP. International Journal of Project Management, 26, 408-419. http://dx.doi.org/10.1016/j.ijproman.2007.05.012

[5] El-Sayegh, S. (2008) Risk Assessment and Allocation in the UAE Construction Industry. International Journal of Project Management, 26, 431-438. http://dx.doi.org/10.1016/j.ijproman.2007.07.004

[6] El-Sayegh, S.M. and Mansour, M.H. (2015) Risk Assessment and Allocation in Highway Construction Projects in the UAE. Journal of Management in Engineering, 31, 04015004. http://dx.doi.org/10.1061/(ASCE)ME.1943-5479.0000365

[7] Zou, P.X.W., Zhang, G. and Wang, J. (2007) Understanding the Key Risks in Construction Projects in China. International Journal of Project Management, 25, 601-614. http://dx.doi.org/10.1016/j.ijproman.2007.03.001

[8] Olawale, Y.A. and Sun, M. (2010) Cost and Time Control of Construction Projects: Inhibiting Factors and Mitigating Measures in Practice. Construction Management and Economics, 28, 509-526. http://dx.doi.org/10.1080/01446191003674519

[9] Enshassi, A., Kumaraswamy, M. and Al-Najjar, J. (2010) Significant Factors Causing Time and Cost Overrun in Construction Projects in the Gaza Strip: Contractors' Perspective. International Journal of Construction Management, 10, 35-60. http://dx.doi.org/10.1080/15623599.2010.10773137

[10] Rahman, I.A., Memon, A.H. and Karim, A.T.A. (2013) Significant Factors Causing Cost Overrun in Large Construction Projects in Malaysia. Journal of Applied Sciences, 13, 286-293. http://dx.doi.org/10.3923/jas.2013.286.293

[11] Wijekoon, S.B. and Attanayake, A.M.C.T.K. (2013) Study on the Cost Overrun in Road Construction Projects in Sri Lanka. http://dl.lib.mrt.ac.lk/handle/123/8969

[12] Alzahrani, J.I. and Emsley, M.W. (2013) The Impact of Contractors’ Attributes on Construction Project Success: A Post Construction Evaluation. International Journal of Project Management, 31, 313-322. http://dx.doi.org/10.1016/j.ijproman.2012.06.006 
[13] Le-Hoai, L., Dai Lee, Y. and Lee, J.Y. (2008) Delay and Cost Overrun in Vietnam Large Construction Projects: A Comparison with Other Selected Countries. KSCE Journal of Civil Engineering, 12, 367-377. http://dx.doi.org/10.1007/s12205-008-0367-7

[14] Thi, C.H. and Swierczek, F.W. (2010) Critical Success Factors in Project Management: Implication from Vietnam. Asia Pacific Business Review, 16, 567-589. http://dx.doi.org/10.1080/13602380903322957

[15] http://m.baodatviet.vn/chi nh-tri-xa-hoi/tin-tuc-thoi-su/bo-truong-thang-noi-ve-duong-viet-nam-dat-gap-3-my-3003911/

[16] Zhao, X.H. (2015) Research on the Control of Project Cost in the Design Stage of Construction Project. Management \& Technology of SME, 4, 168. http://dx.doi:10.3969/j.issn.1673-1069.2015.11.110 